\title{
大型鋳鋼品のX線による残留応力測定*
}

$$
\text { 蒲地一義** 谷昇** }{ }^{* *} \text { 不行 男*** }
$$

\section{X-Ray Stress Measurement of Large Steel Casting}

by

\author{
Kazuyoshi KamaCHI, Noboru TANI \\ (Faculty of Engineering, Yamaguchi University, Ube) \\ and Yukio KIDO \\ (Central Research Laboratory of Ube Kosan Co., Ltd., Ube)
}

\begin{abstract}
The residual stress in a large steel casting $(1000 \times 1000 \times 400 \mathrm{~mm})$ was measured by means of the photographic X-ray method developed in our laboratory. Since the grain size of the steel casting is large, the obtained diffraction lines on the films were spotty and the spots scattered in the radial direction. The peak positions of the diffraction lines was determined by averaging the distance between each diffracted spot and line of the standard substance arithmetically.

The mean value of the residual stress for the specimen annealed at $940^{\circ} \mathrm{C}$ for 16 hours was $7.6 \mathrm{~kg} / \mathrm{mm}^{2}$ in tension on the surface of the feeder head side and $10.5 \mathrm{~kg} / \mathrm{mm}^{2}$ in tension on the surface of the bottom side. The specimen was then cut $15 \mathrm{~mm}$ in depth from the surface of the feeder head side. The mean residual stress on the newly appeared surface was $3.2 \mathrm{~kg} / \mathrm{mm}^{2}$ in compression and it was $7.1 \mathrm{~kg} / \mathrm{mm}^{2}$ in tension on the opposite side. When the specimen was annealed at $650^{\circ} \mathrm{C}$ for 8 hours, the residual stresses on both surface became almost zero. The distribution of the residual stress in the sample were discussed.
\end{abstract}

(Received Sep. 17, 1973)

\section{1 緒言}

鋳鋼は大型機械部材として，多くの方面に用いられ ているが，設計時の許容応力に関して，炎の残留応力 が大きな問題となっている 法等によって測定された例はあるが，表面応力の詳細 な分布を非破壊的に知ることのできるX線法によって 応力測定がなされた例はないように思われる。の理 由として，一般に鋳鋼品は大型部材であることが多く， X線測定法は装置的に困難であること。また，鋳鋼の 特徴として, 結晶粒が大きく, はん点状回折環となっ て，X線応力測定ができなかったことなどによる。

本研究は大型鋳鋼部品であるダイキャストマシンの ムービングプラテンの疲労過程に护将る応力挙動の研 究の一部として, $1000 \times 1000 \times 400 \mathrm{~mm}$, 約 3 トンの 鋳鋼塊の応力をX線的に測定したので，その結果にっ いて報告する。

\section{2 実 験 方 法}

* 原稿受理 昭和48年 9 月17日

** 正会員 山口大学工学部 宇部市常盤台

*** 宇部興应中央研究所 宇部市小串

\section{$2 \cdot 1$ 被測定材}

被測定材は鋳鋼材 (SC 46) である。そ化学成分 をTable I 飞示す。 また光学顕微鏡写真をFig. 1 亿 示す. 試料の寸法は $1000 \times 1000 \times 400 \mathrm{~mm}$ のブロッ クであり, 直径 $670 \mathrm{~mm}$ ，高さ $800 \mathrm{~mm}$ の押湯を付

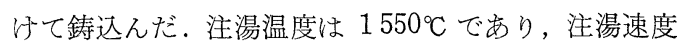
は $74 \mathrm{~kg} / \mathrm{sec} て ゙$ でた. 鋳造後押湯を切断した後, 試料を $940^{\circ} \mathrm{C} ， 16$ 時間保持してから炉冷した。測定は 押湯が兆った面（押湯面）とその反対側の面（底面） について，それぞれ15点の測定点を選んで行なった。 各測定点の位置をFig. 2 亿示す. 試料の対称性を考慮 して，両面とも中心線を含む $1 / 2$ の面について測定点 を選えだ。また測定は $x, y$ 二方向である。各測定点 はいずれもエメリー紙で研摩した後, 電解研摩を施し

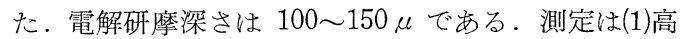
温焼なまし後，(2)押湯面， $15 \mathrm{~mm}$ 切削後，(3)低温焼 なるし $\left(650^{\circ} \mathrm{C}, 8\right.$ 時間保持後炉冷) 後の各処理後, 押湯面，底面の応力を測定した。

$2 \cdot 2$ X 線の条件

X線の条件を Table II に示す。装置は東京芝浦電 
Table I. Chemical composition of SC46.

\begin{tabular}{c|c|c|c|c|c|c|c|c}
\hline $\mathrm{C}$ & $\mathrm{Si}$ & $\mathrm{Mn}$ & $\mathrm{P}$ & $\mathrm{S}$ & $\mathrm{Cu}$ & $\mathrm{Ni}$ & $\mathrm{A} 1$ & $\mathrm{Sn}$ \\
\hline 0.21 & 0.34 & 0.62 & 0.012 & 0.09 & 0.08 & 0.08 & 0.058 & 0.011 \\
\hline
\end{tabular}

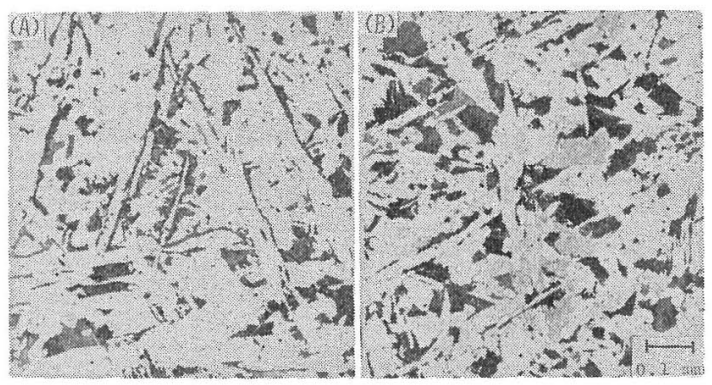

Fig. 1. Optical microscopic photograph of SC46. (A) is the surface of feeder head side. (B) is the surface of opposite feeder head side.

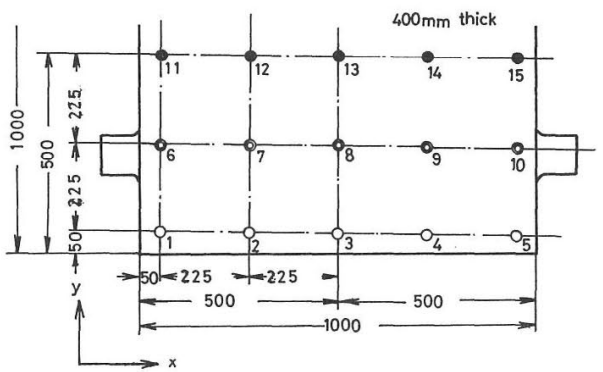

Fig. 2. The dimension of the cast steel block and measured points.

Table II. Condition of X-ray stress measurement.

\begin{tabular}{l|l}
\hline Apparatus & Toshiba MDP 103 \\
X-ray & $\mathrm{CrK} \alpha_{1}$ (V filter) \\
Voltage, current & $30 \mathrm{kV} 8 \mathrm{~mA}$ \\
Diffraction plane & $\{211\}$ \\
Comparative substance & $\mathrm{Cr}$ powder \\
Camera length & $50 \mathrm{~mm}$ \\
Collimator & $1 \mathrm{~mm} \phi$ double pinhole \\
Incident angle & $0^{\circ}, 45^{\circ}$ \\
\hline
\end{tabular}

気製 MDP 103 を使用した。 X線はVフィルタを透 過した $\operatorname{CrK} \alpha$ 線であり, 回折面は $\{211\}$ である. 標 準物質は材料学会仕㥞の Cr 粉木を用いた。露出時間 は1時間である。試料は固定したままであるが，入射 角を政に対して士2. $5^{\circ}$ 不連続的に变動して撮影した。 入射角は, 多くの測定点について測定するため, $0^{\circ}-$ $45^{\circ}$ 法を用いた。フィルムはフジ $K_{X}$ 医療用を使用し た。

\section{$2 \cdot 3$ ピーク位置の決定}

以上のような条件で撮影したフィルムの一例をFig. 3 に示寸。写真からわ加るよなは九点状回折環が 得られた.このフィルムの測定方向を0-0で示し,
0-0 から円周力向に上10の範围にある $\mathrm{K} \alpha_{1}$ 線によ って回折した $n$ 個のはえ点について, 標準物質回折線 からの距離を、フィルムの中心を通る直径線上で測定 した．測定はコンパレータによって，バーニアスケー ルで読んだ. 個々のはん点から標準物質までの距離を $\Delta \Psi i$ とすると, ピーク位圆 $\overline{\Delta \Psi}$ は次式で決まる。

$$
\overline{\Delta \Psi}=\frac{\sum_{i=1}^{n} \Delta \Psi i^{2)}}{n}
$$

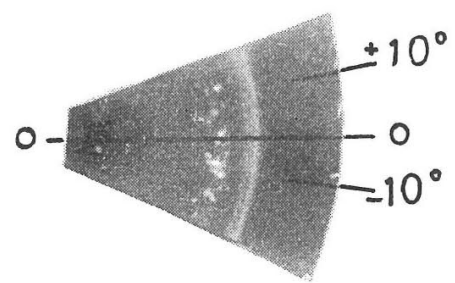

Fig. 3. Spotty X-ray ring.

\section{3 実 験 結 果}

(1) Fig. 4，5に高温焼なま乙後の，押湯面および 底面の応力分布を示す。 ○は試料の縁から $50 \mathrm{~mm}$ の $x$ 方向の列を示す。は試料の縁から $275 \mathrm{~mm}$, また $500 \mathrm{~mm}$ の測定線上の測定值を示す.これらの記 号はFig. 2 に打ける測定点の記号に準じている。以下 同様の記号で応力分布を示して山る. Fig. 4 に执いて， 高温焼な屯し後の押湯面の応力は各測定点でいずれも 引張応力である。応力值の分布については, 測定值は 局部的応力を意味して和り，連続した応力の分布は不 明確であるが，中央部の応力值は周辺部のそれと比較 して高い引張応力が存在する傾向にある. Fig. 5 は高 温焼なまし後の底面の応力分布を示しているが，押湯

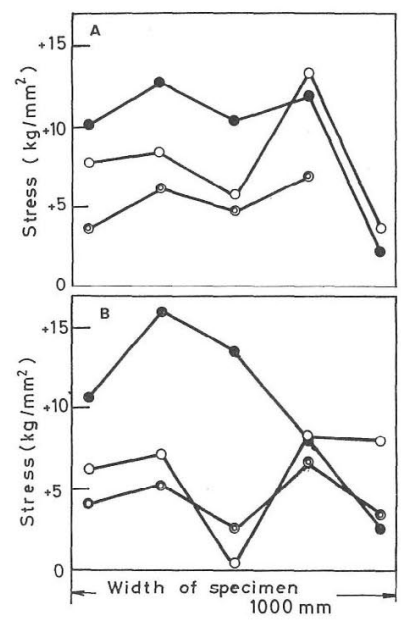

Fig. 4. Distribution of residual stress on the surface of feeder head side after the annealing treatment at $940^{\circ} \mathrm{C}$ for 16 hours. A : $x$ direction B : $y$ direction. 

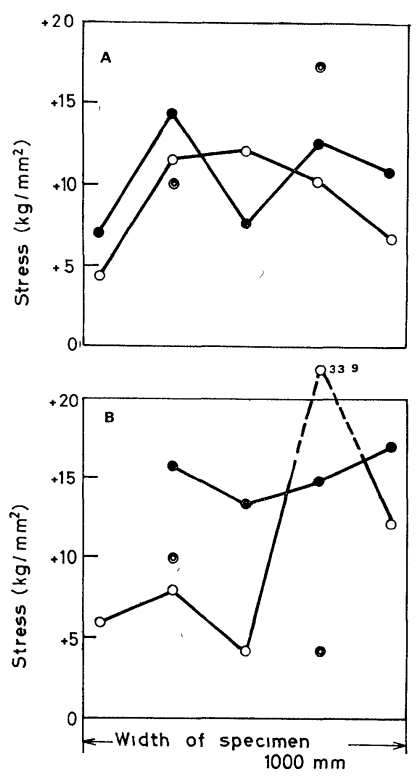

Fig. 5. Distribution of residual stress on the surface of bottom side on the case of anneal ed at $940^{\circ} \mathrm{C}$ for 16 hours. A : $x$ direction B: $y$ direction.

面と同様の傾向を示している。

（2）押湯面を $15 \mathrm{~mm}$ 切削除去した後の応力測定を 行ならため，切削加工による加工ひずみの影響を調べ た.との結果をFig. 6 に示す。横軸は電解研摩深さで あって, 切削面には $36 \mathrm{~kg} / \mathrm{mm}^{2}$ 程度の引張応力があ り, 得られた回折線も連続回折環である。電解研摩深 さの值が大きくなるにつれて, 応力は減少して, 表面 から $80 \mu$ 程度より深くなると注注一定值に落ち着い た、また回折線の状況も焼なまし後の写真と同様なは ん点状となった。したがって，切削加工は表面から約 $80 \mu$ までその影響が及ぶと判断して，電解研摩深さは $100 \mu$ 以上とした．Fig. 7 は切削された押湯面につい ての残留応力分布である.この図と切削前のFig. 4 を 比べると，押湯面を $15 \mathrm{~mm}$ 切削除去することによっ て全体的に引張応力から圧縮応力に変化した。すなわ ら表面から $15 \mathrm{~mm}$ 樑さの間に $10 \mathrm{~kg} / \mathrm{mm}^{2}$ 程度の応 力こう配が存在する.Fig. 8 にその時の底面側の応力 分布を示す．底面側は切削前と同様に全体としては引 張応力であるが，押湯面を切削することによって，試 料中央部の応力は増加して, 周辺部では減少する傾向 にある. 切削前, 切削後の底面の応力を平均值で比較 すると, 応力は $3.4 \mathrm{~kg} / \mathrm{mm}^{2}$ 低下した。

（3）試料を $650^{\circ} \mathrm{C} ， 8$ 時間の低温応力除去焼なまし を行なった後に測定した応力值を押湯面，底面につい てそれぞれFig. 9，10に示す。この処理によって，表 面の残留応力は大幅に除去され，押湯面 $x$ 方向でその 平均值は $-0.6 \mathrm{~kg} / \mathrm{mm}^{2}, y$ 方向は $+0.5 \mathrm{~kg} / \mathrm{mm}^{2}$ で

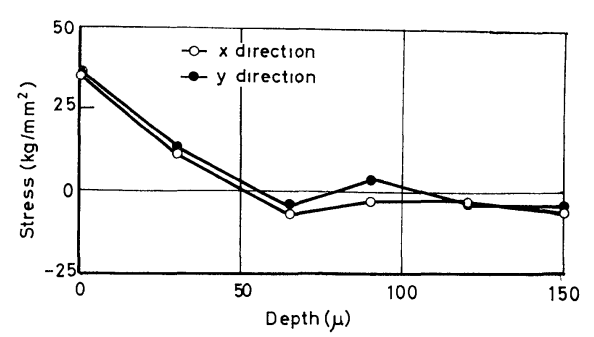

Fig. 6. Effect of the cutting at point No. 3.

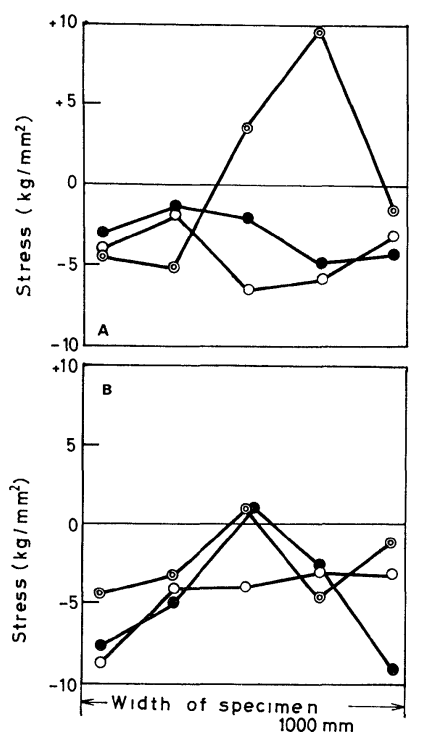

Fig. 7. Distribution of residual stress on the surface of feeder head side after cutting 15 $\mathrm{mm}$ in depth. A : $x$ direction $\mathrm{B}: y$ direction.

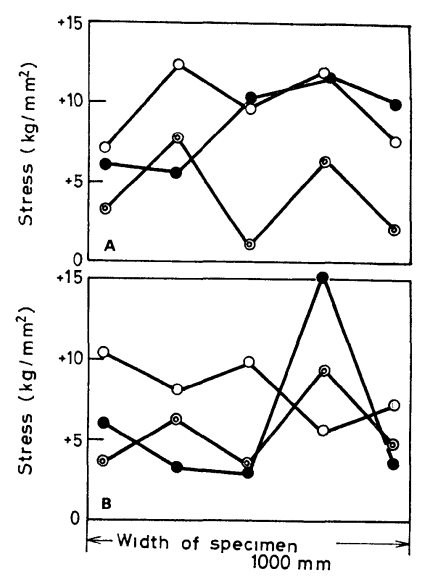

Fig. 8. Distribution of residual stress on the surface of bottom side which is another surface of cutting. A: $x$ direction B: $y$ direction.

あった。底面側は平均値で， $x$ 方向は $+1.5 \mathrm{~kg} / \mathrm{mm}^{2}$, $y$ 方向は $+3.7 \mathrm{~kg} / \mathrm{mm}^{2}$ の值を得た.

$$
4 \text { 考 }
$$

察

\section{$4 \cdot 1$ はん点の分布}




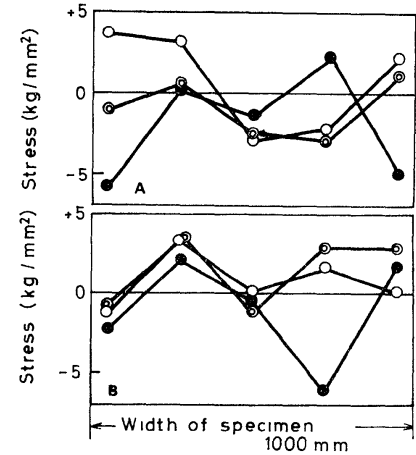

Fig. 9. Distribution of residual stress on the surface of feeder head side on the case of annealed at $650^{\circ} \mathrm{C}$ for 8 hours. A : $x$ direction B: $y$ direction.

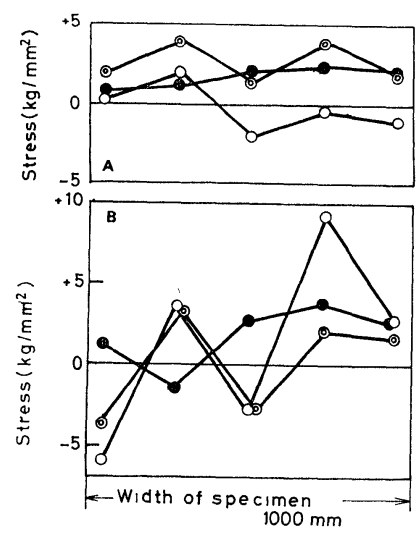

Fig. 10. Distribution of residual stress on the surface of bottom side on the case of annealed at $650^{\circ} \mathrm{C}$ for 8 hours. A : $x$ direction B : $y$ direction.

フィルム上に現われるはん点の個数とはん点の分布 について調べたところ，測定方向に対して $\pm 10^{\circ}$ の範 囲にある $\mathrm{K} \alpha_{1}$ 線によって回折したはん点の個数は 10 個から23個であった。すべてのフィルムを平均すれば 13.6個である.これらはん点の半径方向の分布は正規 分布であるべきであって，その個数分布の一例をFig. 11 飞示す！それらの分布曲線のピークから得られた $\sin ^{2} \Psi$ $\Psi \Psi$ 線図はFig. 12 のようであった。余程の粗 結晶等に遭遇した場合を除いては大略 Fig. 12 (B), (C) に示す程度であって，大略の応力值の推定は可能であ る、鋳鋼等設計時の許容応力值が低いこと, 和よびこ の方法の性格から高精度の測定は困難ではあったが， 以上の程度のバラッキで, $\sin ^{2} \Psi-\Delta \Psi$ 線図の傾斜から 考学て，和和よその值は測定できたと考光る。

\section{$4 \cdot 2$ 応力の分布}

大型鋳鋼品の冷却過程に执いては，外周部の方か中 心部に比べて当然早く冷却するので, 外周部は中心部 に対して引張りの応力となる. (Fig. $13(\mathrm{~A})$ ) この応力

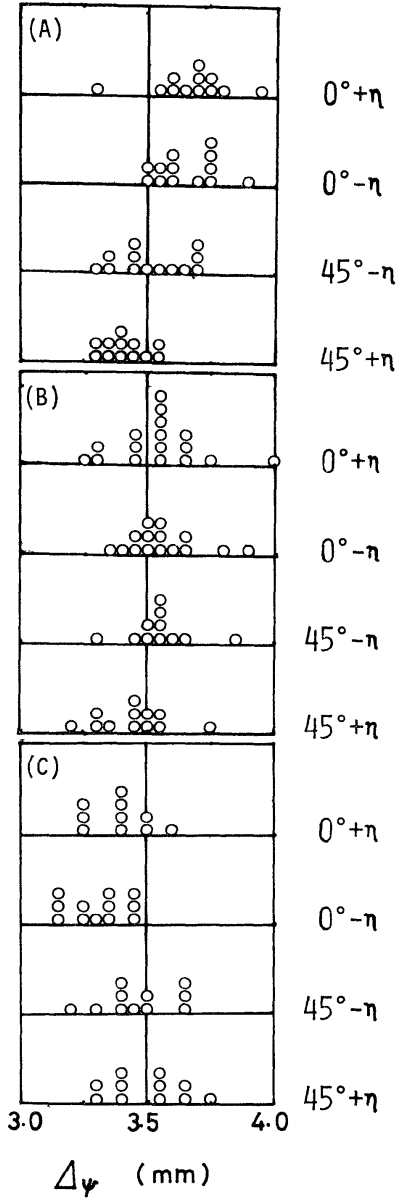

Fig. 11. (A), (B), and (C). Examples of distribution of spots.

が大きいときには，降伏点は高温では低いので塑性変 形を起こし，Fig. 13(B)のようになると考光られる。 さらに温度が低下すると，試料は全体として冷却する ため，外周部に対して相対的に中心部が伸びた状態に あるので, 室温に冷却した場合子外周には引張応力が かかる. (Fig. 13 (C)) な和, hot ingot の応力測定例 として，室温に和ける ingot の外周に圧縮応力が残 る例があるが，鋳造応力は試験体の形状，大きさ，抒 よび冷却条件等によって簡単にきまるるのではないと 考光る.

また表面を $15 \mathrm{~mm}$ 切削したため, 応力值が零に近 く, Fig. 7 のように（一部圧縮側に入る）なるのは， $15 \mathrm{~mm}$ の切削深さが Fig. 13 (C)の $P$ 点付近にあると想 像される. 片面 $15 \mathrm{~mm}$ の切削で他面の応力が変化す るのは応力の再配分が起こったためであり，Fig. 8 の 結果は妥当な変化であるとい劣る。

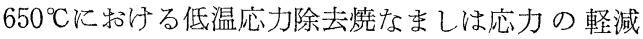
に有効であることが Fig. 9，10 の結果から明らかとな 

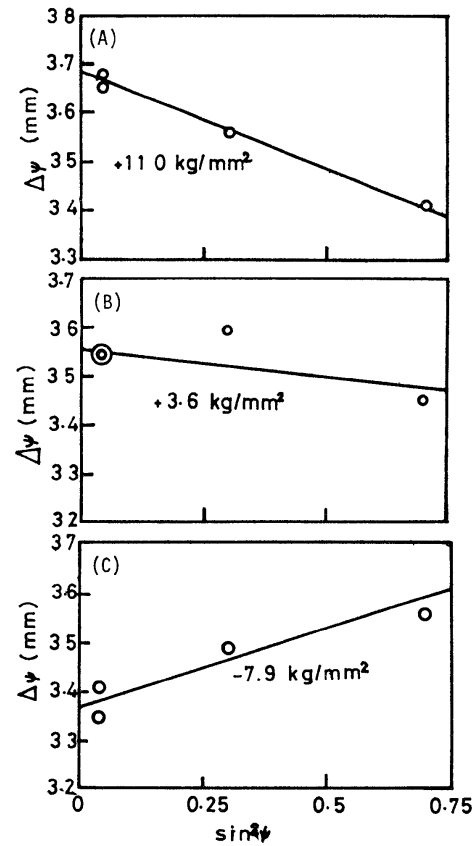

Fig. 12. (A), (B) and (C). Examples of $\sin ^{2} \Psi$ $\Delta \Psi$ diagram.

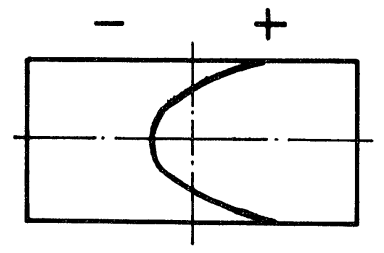

(A) After solidification

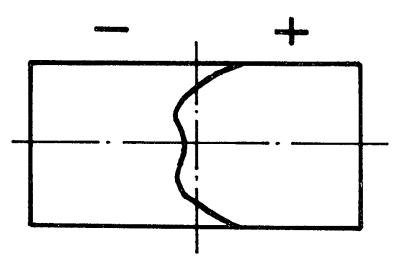

(B) Plastic deformation occur in the block

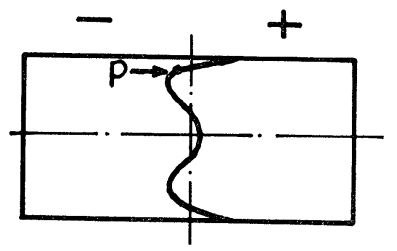

(C) At room temperature

Fig. 13. Development of residual stresses during cooling.
った。

測定值に関して, 高温燒なまし後の押湯面の測定值 を平均すると $x$ 方向に $7.8 \mathrm{~kg} / \mathrm{mm}^{2}, y$ 方向に 7.4 $\mathrm{kg} / \mathrm{mm}^{2}$ の引張応力があった。 また底面側では $x$ 方 向に $10.4 \mathrm{~kg} / \mathrm{mm}^{2}, y$ 方向に $10.5 \mathrm{~kg} / \mathrm{mm}^{2}$ の平均 引張応力を得た. 押湯面を $15 \mathrm{~mm}$ 切削除去すると, この面に $x$ 方向で $2.4 \mathrm{~kg} / \mathrm{mm}^{2}, y$ 方向に $4.0 \mathrm{~kg} /$ $\mathrm{mm}^{2}$ の平均圧縮応力があり，その時の底面側の平均 応力は, $x$ 方向に $7.5 \mathrm{~kg} / \mathrm{mm}^{2}, y$ 方向に $6.7 \mathrm{~kg} /$ $\mathrm{mm}^{2}$ の引張応力であった． 測定面の形状が正方形で あるため, $x$ 万向,$y$ 万向の平均応力が注ぼ同様な值 になったと考えられる。

\section{5 結言}

本研究の意義は, 次の諸点にあると考学られる.

(1) $1000 \times 1000 \times 400 \mathrm{~mm}$ の大型鋳鋼品の応力を 測定した．測定ははん点法によって有効に行なわれた．

（2）鋳造応力分布はほぼ理論ど特りであると考えら れる。

（3）低温応力除去焼なましが有効であることがわか った。すなわち応力軽減の目的を達していると考光ら れる。

な敃在， $300 \times 300 \times 100 \mathrm{~mm}$ の直方体鋳造品につ いて同様の測定を繰り返して, 本研究の成果を追試し

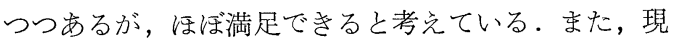
時点では, フィルム上のはん点と標準物質回折線間の 距離 $\Delta \Psi$ を一つ一つコンパレータを用いて測定してい るが，自動的にこの距離を測定することのできるミク ロフォトメータの使用によって，この読み取りの手間 が省かれる。このミクロフォトメータについて開発し たいと考えている。

(昭和48年 8 月 22 日 第 1 回材料の力学的挙動に関するシンポジウムに て講演)

\section{考文 献}

1）日本鉄鋼協会，“鉄鋼製造法”，第 4 分冊， p. 69 (1972) 丸善

2) 蒲地一義, 谷昇, 材料, 21, 1112 (1972).

3) Dieter, G. E, “Mechanical Metallurgy”, p. 395 (1961) McGraw-Hill 